relatively new but fashionable 1,5benzodiazepine, clobazam is not. The TLC procedure relies on the hydrolysis of benzodiazepines or their metabolites to aminobenzophenones which are detected by their yellow colour, fluorescence characteristics and, in the case of primary aminobenzophenones, the formation of an azo dye. Whereas the 1,4-benzodiazepines readily undergo cleavage to the corresponding open-ringed benzophenone, no such similar reaction occurs with clobazam or its pharmacologically similar metabolite, Ndesmethylclobazam.

We conclude that TLC of the acid hydrolysate will lead to false negative results when clobazam has been ingested, and laboratories using this methodology for benzodiazepine screening should note this exception.

NR BADCOCK GD ZOANETTI

Department of Chemical Pathology, The Adelaide Children's Hospital, North Adelaide, South Australia, 5006 Australia

Reference

1 Widdop B. ACP Broadsheet 119: Simple tests to detect poisoning. J Clin Pathol 1988;41: 996-1004.

\section{Hepatitis B (HbsAg and HBcAg) hepatic markers in HBsAg positive chronic liver disease}

Patients without circulating hepatitis B surface antigen (HBsAg) can none the less have positive viral markers in liver tissue. Usually such patients have high serum titres of anti-hepatitis B core (anti-HBc) antibodies. Several explanations for this phenomenon have been suggested, including low $\mathrm{HBsAg}$ concentrations undetectable by traditional diagnostic methods and immunocomplex formation with circulating antibodies.

Recently Cuccurullo et al ${ }^{1}$ showed that $17 \%$ of alcoholic patients and $21 \%$ of nonalcoholic patients were positive for $\mathrm{HBsAg}$ or $\mathrm{HBcAg}$ (core antigen) in liver tissue, despite being seronegative for all serum markers of hepatitis B virus. We studied liver markers (HBsAg and $\mathrm{HBcAg}$ ) on a total of 60 patients with chronic liver disease and seronegative for $\mathrm{HBsAg-30}$ with alcoholinduced hepatic disease and 30 with nonalcohol-induced hepatic disease. In all cases hepatitis serum B virus markers were studied using ELISA techniques (HBsAg, anti-Hbs, anti-HBc, $\mathrm{HBeAg}$ and anti-HBe), and liver tissue markers ( $\mathrm{HBsAg}$ and $\mathrm{HBcAg}$ ) with immunoperoxidase.

Fourteen patients had anti-HBs associated with anti-HBc; only a single patient was seropositive for anti-HBc alone. The rest were all hepatitis B virus seronegative. None had positive tissue markers for hepatitis B virus (HBsAg, $\mathrm{HBcAg}$ ).

Our findings suggest that it is highly unlikely that a seronegative patient will display $\mathrm{HBsAg}$ or $\mathrm{HBcAg}$ in the liver. It is also unlikely that such a patient will have liver disease related to hepatitis $B$. These findings contradict, to some extent, those of Cuccurullo et al,' but the difference is unlikely to be due to geographical factors or methodological variables, because our serum HBsAg positive patients showed highly sensitive and specific hepatic markers.

FJS ESCOBAR JT GILABERT TC MORALES Servicio de Digestivo. Hospital Iniversitario, Granada, Spain

\section{Reference}

1 Cuccurullo L, Rambaldi M, Iaquinto G et al. Importance of showing $\mathrm{HBsAg}$ positivity in the liver for better aetiological definition of chronic liver disease $J$ Clin Pathol 1987;40:167-71.

\section{Dr Rimbaldi et al comment:}

Salmeron Escobar et al report that none of the 60 patients with chronic liver disease seronegative for HBsAg studied showed positive tissue markers for hepatitis $B$ virus ( $\mathrm{HBsAg}$ and $\mathrm{HBcAg}$ ), which is contrary to our previous data.' Many authors have reported positive tissue markers for $\mathrm{HBsAg}$ or $\mathrm{HBcAg}$ in the absence of $\mathrm{HBsAg}$ or $\mathrm{HBcAg}$ in both alcoholic and non-alcoholic patients. Further observations, conducted in a wider range of cases $(n=164)$ confirm our previous data (table). In all cases we verified the specificity of the method as reportef elsewhere. ${ }^{1}$

In contrast to the findings of the Spanish authors, we maintain that geographig factors could have had a certain effect on the discrepancy found between their data a those of the other authors, ours include Indeed, only 15 of the 60 hepatic patien $(25 \%)$ that they studied showed anti-HBs or anti-HBc, or both, in the serum, whigh probably reflects a low percentage of hepatitis B infection in their population. TRe spectrum of this infection does, indeed, vary in different parts of Europe-for example, alcoholics with chronic liver disease the positive percentage oscillates between 10 a d $40 \%$; in Northern Europe ${ }^{2-3}$ it is $45 \%$ in French survey ${ }^{4}$ and reaches $75 \%$ in an Italian survey. ${ }^{5}$ This most probably reflects varyifg risks of exposure in different countries.

One could also hypothesise that at leasti part of chronic liver disease with $\mathrm{HBsAg}$ afd $\mathrm{HBcAg}$ negative tissue could be the result of infection with the non-A, non-B hepatitis $\$$ virus.

\section{References}

1 Cuccurullo L, Rambaldi M, laquinto G, et $\overrightarrow{\vec{\sigma}}$ Importance of showing $\mathrm{HBsAg}$ and $\mathrm{HBc}$ positivity in the liver for better aetiological definition of chronic liver disease. $J$ 蔗 Pathol 1987;40:167-71.

2 Hislop W, Follet E, Bouchier I, MacSween Serological markers of hepatitis B in patieg with alcoholic liver disease. A multicentue survey. J Clin Pathol 1981;34:1017-19.

3 Orholm M, Aldershvile J, Tage-Jensen U, et बि Prevalence of hepatitis B virus infectiō among alcoholic patients with liver disease $J$ Clin Pathol 1981;34:1378-80.

4 Buffet C, Attali P, Papoz L, Chaput JC, Etienire JP. Evidence for previous hepatitis B vir infection in alcoholic cirrhosis. Dig Dis 1982;27:473-4.

5 Adelasco L, Monarca A, Dantes M, et ol Features of chronic hepatitis in alcoholics. survey in Milan. Liver 1987;7:283-9.

Distribution of serum and tissue positivity in alcoholic and non-alcoholic patients

\begin{tabular}{|c|c|c|c|c|c|}
\hline \multirow{2}{*}{$\begin{array}{l}\text { Liver } H B s A g \text { or } \\
H B c A g, \text { or both }\end{array}$} & \multirow{2}{*}{$\begin{array}{l}\text { At least } \\
\text { one marker }\end{array}$} & \multicolumn{2}{|c|}{ Alcoholics } & \multicolumn{2}{|c|}{ Non-alcoholics } \\
\hline & & $\bar{n}$ & $(\%)$ & $\bar{n}$ & $(\%)$ \\
\hline $\begin{array}{l}\text { Tissue positive } \\
\text { Tissue negative } \\
\text { Tissue positive } \\
\text { Tissue negative }\end{array}$ & $\begin{array}{l}\text { Serum positive } \\
\text { Serum negative } \\
\text { Serum negative } \\
\text { Serum positive }\end{array}$ & $\begin{array}{l}15 / 71 \\
30 / 71 \\
13 / 71 \\
13 / 71\end{array}$ & $\begin{array}{l}(21 \cdot 12) \\
(42 \cdot 25) \\
(18 \cdot 30) \\
(18 \cdot 30)\end{array}$ & $\begin{array}{l}15 / 93 \\
28 / 93 \\
20 / 93 \\
30 / 93\end{array}$ & $\begin{array}{l}(16 \cdot 13) \\
(30 \cdot 10) \\
(21 \cdot 50) \\
(32 \cdot 25)\end{array}$ \\
\hline
\end{tabular}

